\title{
Dendrochronological Potential of Drought-Sensitive Tree Stands in Armenia for the Hydroclimate Reconstruction of the Lesser Caucasus
}

\author{
Magdalena Opała-Owczarek 1,*(D), Hrachuhi Galstyan ${ }^{2}$, Piotr Owczarek ${ }^{3}\left(\mathbb{D}\right.$, Hovik Sayadyan $^{4}(\mathbb{D})$ \\ and Trahel Vardanyan ${ }^{4}$ (D) \\ 1 Institute of Earth Sciences, University of Silesia in Katowice, 41-200 Sosnowiec, Poland \\ 2 School of Life Sciences, Neijiang Normal University, Neijiang 641112, China; hrachuhigs@gmail.com \\ 3 Institute of Geography and Regional Development, University of Wroclaw, 50-137 Wroclaw, Poland; \\ piotr.owczarek@uwr.edu.pl \\ 4 Faculty of Geography and Geology, Yerevan State University, Yerevan 0025, Armenia; \\ hovik.sayadyan71@gmail.com (H.S.); tvardanian@ysu.am (T.V.) \\ * Correspondence: magdalena.opala@us.edu.pl
}

check for updates

Citation: Opała-Owczarek, M.; Galstyan, H.; Owczarek, P.; Sayadyan, H.; Vardanyan, T.

Dendrochronological Potential of Drought-Sensitive Tree Stands in Armenia for the Hydroclimate Reconstruction of the Lesser Caucasus. Atmosphere 2021, 12, 153. https: / / doi.org/10.3390/atmos 12020153

Academic Editor: Chuixiang Yi

Received: 18 December 2020

Accepted: 21 January 2021

Published: 26 January 2021

Publisher's Note: MDPI stays neutral with regard to jurisdictional claims in published maps and institutional affiliations.

Copyright: (C) 2021 by the authors. Licensee MDPI, Basel, Switzerland. This article is an open access article distributed under the terms and conditions of the Creative Commons Attribution (CC BY) license (https:/ / creativecommons.org/licenses/by/ $4.0 /)$.

\begin{abstract}
Existing high-resolution reconstructions of hydroclimate variability in the Caucasus are lacking tree-ring data from Armenian Plateau, the most continental part of the region. Our research presents the first dendrochronological investigation in Armenia. Juniper and oak tree-ring width chronologies were constructed, the longest spanning the last 140 years. The positive influence of spring-summer precipitation and the negative influence of temperature suggest drought stress at the investigated sites. Moving correlation analysis indicated a significant change over time in the sensitivity of investigated trees to climatic variability; juniper, previously sensitive to both temperature and precipitation, has shown especially strong precipitation signals in the recent decades since the local climate has turned more arid. Ongoing climate change increases drought stress in juniper, which may have further consequences on semiarid ecosystems. Our results reveal multiannual droughts recorded by tree rings, emerging in most parts of the Black Sea-Caspian Sea region.
\end{abstract}

Keywords: dendroclimatology; drought; tree-ring width; juniper; oak; Armenia; Lesser Caucasus

\section{Introduction}

The Armenian Plateau and the Lesser Caucasus region are vulnerable to climate change and its impact on hydrological balance [1]. In the 20th century, there was a significant air temperature increase in this region; the annual mean temperature increased by $1^{\circ} \mathrm{C}$ between 1935 and 2012. The opposite trend was observed in precipitation, which decreased by almost 10\% between 1935 and 2012. Thus, over recent decades, the climate in the Ararat Valley, a central region of the country, has turned more arid and, consequently, most agricultural areas have undergone a process of desertification [2]. The Armenian Plateau is relatively well isolated from marine influences, being the most continental part of the Caucasus [3]. As nearly half of the arable land in Armenia requires irrigation, the projected temperature rise, intensification of evaporation, and precipitation decrease will further worsen the desertification problem and opportunities for Armenian agriculture [4]. The negative consequences will also include public health and sectors that depend on the climate and changes in the biodiversity of natural ecosystems.

Available instrumental meteorological records do not provide an adequate temporal scale for investigating the long-term patterns of the emergence of dry/wet events and the possible causes. Good quality climate station data, with a relatively low number of gaps, exist only for the period 1961-2012 and for a limited number of stations [1,2,5]. Single station data can go back to the 19th Century in exceptional cases-Yerevan from 1885; 
however, there are occurrences of missing data in the early part of this data series. As the climate change rate varies both in spatial and temporal scales, it is crucial to investigate climate variability in the period before the availability of instrumental records.

In this context, the major challenge for assessing climate change in the Lesser Caucasus region is the development of a proxy series for climate reconstruction to evaluate the history of past droughts and wet periods. Unfortunately, few paleoclimate data are available for the Armenian Plateau and the Lesser Caucasus region. Existing climatic reconstructions are based on lacustrine sediments [6,7], travertine deposits [8], or pollen-based records [9] and relate to environmental changes during the Holocene or for even longer time scales with low temporal resolutions. Past climatic variations over the last millennium or hundreds of years remain unclear. It seems that dendrochronological data from this region can reveal potentially useful climatic signals. Dendroclimatological records are some of the most important natural archives for studies of the Holocene climate in high resolution [10]. Centennial-length records of precipitation can be developed based on dendrochronological records from the regions where precipitation is the main limiting factor [11]. It is well known that tree radial growth indices can be valuable long-term measures of tree conditions and can thus serve as an indirect drought indicator $[12,13]$. Tree-ring data from arid and semiarid regions have been extensively used in paleoclimate reconstructions of precipitation and drought conditions in many parts of Asia: Mongolia [14,15], Tien Shan [16,17], Pamir-Alay [18-20], and Zagros Mountains [21,22]. Dendroclimatological studies have also been accomplished in the northern Caucasus, where tree-ring width [23], density [24], stable isotopes [25], and blue intensity data [26] were utilized for dendroclimatic reconstruction of summer temperatures. Tree-ring width chronologies from single sites from the western Lesser Caucasus in Georgia and the eastern Pontic Mountains in Turkey were utilized to reconstruct spring temperatures [27] and spring precipitation [28]. The floating tree-ring series for Armenia was developed based on Bronze Age oak charcoals from the archaeological site at Gegharot [29]. However, to our knowledge, no dendrochronological and dendroclimatological data from living trees in Armenia have been developed so far.

To determine past climatic variability and to place current hydroclimatic conditions in a broader context, we addressed the following research questions: (1) Which climatic factors affect the radial growth of Juniperus polycarpos and Quercus macranthera? (2) What is the spatio-temporal stability of the obtained dendroclimatic signal? (3) What is the potential for palaeoclimatological reconstruction in the Armenian Plateau and the Lesser Caucasus region based on tree rings?

\section{Study Area}

The Republic of Armenia is located in the northeast of the Armenian Highlands, at the border of the Caucasus and western Asia. The study area is located in the Lesser Caucasus mountains belonging to the large and morphologically and geologically diverse Black Sea-Caspian Sea region (Figure 1A). This area is largely determined by its position between the Eurasian and Africa-Arabian lithosphere plates, within a wide collision zone [30,31]. The Lesser Caucasus (max. elev. Aragats, $4090 \mathrm{~m}$ a.s.l.) is situated between the Transcaucasus in the north and the Armenian Upland in the south, stretching from the Black Sea to the Araks river valley for a distance of about $600 \mathrm{~km}$. The mountains have fold and fault-block structures consisting of a series of parallel mountain ranges and tectonic depressions. The research sites are located in the central part of the Lesser Caucasus: the Geggham Mountains (max elev. Azhdahak 3997 m a.s.l.) and the Tsaghkunyats Mountains (max elev. Teghenis $2851 \mathrm{~m}$ a.s.l.) (Figure 1B). These mountain ranges are built of TertiaryQuaternary subaerial volcanic rocks, which create a high elevated plateau, lava domes, and cinder cones cut by deep valleys with steep slopes [32,33]. 

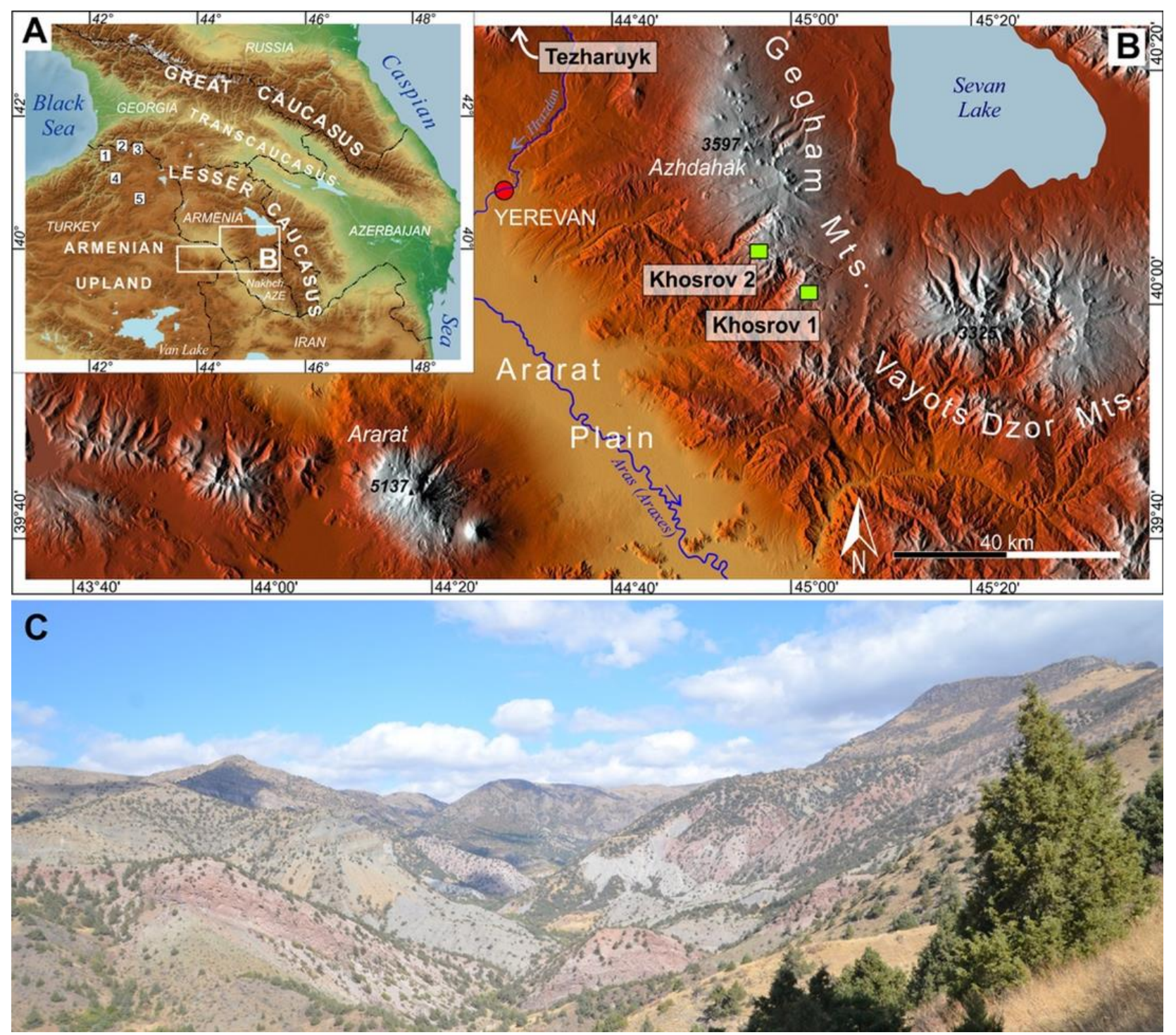

Figure 1. Map of the Armenian Plateau and the Lesser Caucasus region between the Black Sea and the Caspian Sea showing the location of previously published chronologies (A): 1-Abies nordmanniana [27]; 2-Pinus pinea, Pinus sylvestris, Quercus petraea [28]; 3-Pinus sylvestris [34]; 4-Pinus sylvestris [35]; 5-Pinus sylvestris [36], and new sampling sites in Gegham Mountians (B). General view of the study area covered with open woodlands dominated by juniper trees (C).

Armenia has a wide variety of climatic conditions, caused mainly by its location between the Black Sea and the Caspian Sea and the country's complex and rough topography, which affects the composition and direction of air masses. A westerly circulation, which penetrates from the Eastern Mediterranean and the Black Sea, brings moist air over the Caucasus and provides snowfall in winter and rainfall in spring. These dynamics are affected by two main anticyclones: centered in western Russia in winter and over Scandinavia and western Europe during spring [37].

Mountainous relief and aspects are correlated with the distribution of dominant air masses within the country that influence the formation and modification of the temperature field. Significant climate diversity over even a small territory is observed because of the intricate terrain. The country has almost all types of climate, from arid subtropical to cold high mountainous climates. The average annual air temperature is $5.5^{\circ} \mathrm{C}$. The average annual temperature is below zero at altitudes above $2500 \mathrm{~m}$. The warmest month is July with an average temperature of $16.7^{\circ} \mathrm{C}$, while in the Ararat Valley it has a range of $24-26^{\circ} \mathrm{C}$. 
January is the coldest winter month, with an average temperature of $-6.7^{\circ} \mathrm{C}$. The absolute temperatures range from -42 to $43.7^{\circ} \mathrm{C}$ [38] (Figure 2).
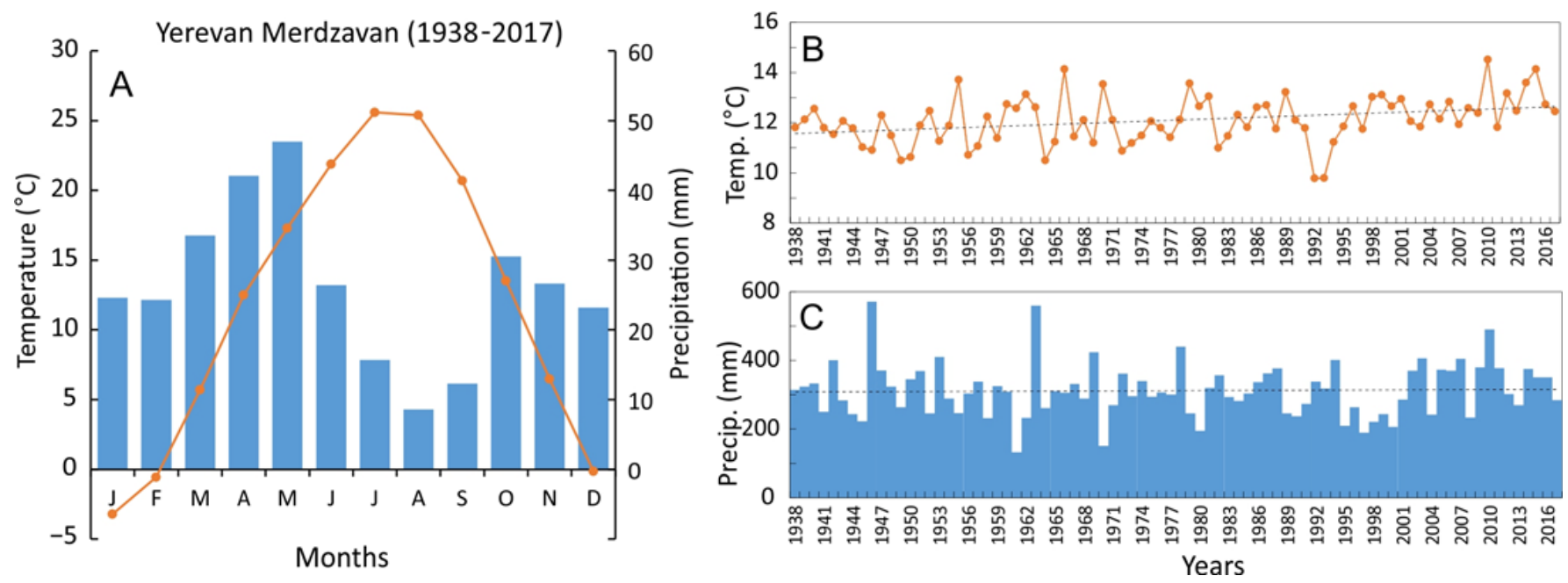

Figure 2. Regional climate diagram of the central Lesser Caucasus Mountains based on Yerevan Merdzavan meteorological station data over 80 years (1938-2017): (A) monthly mean temperature and precipitation, (B) long-term annual mean temperature, and (C) annual precipitation. Dashed lines represent trends in climatic data.

The average annual air temperature in Armenia increased by $0.9{ }^{\circ} \mathrm{C}$ in the $1961-2012$ period and by $0.6^{\circ} \mathrm{C}$ during $1990-2012$ [2,39]. Two clearly distinguished periods of longterm trends can be revealed: temperature trends were nearly zero at most stations in Armenia for the 1961-1994 period but positive and statistically significant for 1979-2012 in most cases. A very clear signal of warming was detected at most stations in Armenia for spring, summer, and autumn seasons for 1979-2012 (statistically significant). Negative temperature trends have been found in south-western part of Armenia for the winter season, as a result of an increase in the occurrence of near-surface inversions. The higher air temperatures in the warm season would be expected to increase evaporation and therefore reduce the availability of water [40].

Rainfall patterns in the region are affected by the dynamics of the North Atlantic Oscillation (NAO), east Atlantic/western Russia (EA/WR), and North Sea Caspian (NCP) atmospheric teleconnections patterns [41,42]. The Armenian Plateau, which induces a local high-pressure system in winter and a low-pressure system in summer, is relatively well isolated from marine influences, being the most continental part of the Caucasus [3]. The average annual precipitation amounts to $592 \mathrm{~mm}$. The most arid zones are the Ararat Valley and the Meghri region, with annual precipitation of around 200-250 mm. Maximum precipitation is recorded in the high mountainous areas at around $1000 \mathrm{~mm}$ per year. In the annual course of precipitation, the minimum is observed in the summer months (in the Ararat Valley it does not exceed $35 \mathrm{~mm}$ ), while the maximum occurs in the spring (Figure 2). However, the precipitation gradient is very variable and complicated from one slope to another, as a result of the steepness of the slope and the diverse orography in relation to the incoming air masses [3]. Precipitation change has been observed since the 1990s over most of the territory of Armenia. The precipitation has a positive trend in relatively low areas and valleys below $2000 \mathrm{~m}$, but it has a negative trend in almost all high mountainous areas above $2000 \mathrm{~m}$ [43].

The Lesser Caucasus is included in the Caucasus and Irano-Anatolian biodiversity hotspots. Biomes range from a semidesert in the Ararat Plain to subalpine and alpine in the high mountainous areas. The samples were taken from two sites within the Khosrov Forest State Reserve, which covers the south-western part of the Geggham Mountains, and the Tezharuyk site located in the Tsaghkunyats mountain (Figure 1B). There is a great diversity of soil cover associated with the vertical zonation of lithological and bioclimatic 
conditions. In the study sites, Mollic Umbrisols (brown mountainous-steppe soils) and Albic Luvisoils (grey forest soils) transitioning to Phaeozems (black mountainous-forest soils) are the most common. The vegetation of this area is strongly limited by humidity and temperature relations. Arid sparse forest with juniper (Juniper communis, J. polycarpos and J. oblonga) and oak (Quercus macranthera) can be found at the altitude of $1400-2300 \mathrm{~m}$ a.s.l. The southern steep sunny and dry slopes are covered by juniper trees, which often form open woodlands with specific xeric vegetation, while the northern and western mountainous slopes are overgrown by oak forest [44] (Figure 1C).

\section{Materials and Methods}

\subsection{Site Description}

The tree samples of juniper were taken from the Khosrov area, which was established in 1958 as the first national forest reserve in Armenia. This reserve was designed to protect valuable or rare trees species-e.g., juniper (Juniperus policarpos K. Koch, J. sabina Georgi, J. foetidissima Wild) [45]. The juniper forest only covers $2.5 \%$ of the total forest area in Armenia [46]. Old-growth forest is scarce despite the protection of this area by Armenian kings. The Khosrov reserve is located in easily accessible areas in the middle of the Ararat Plain, which was converted for agricultural use a long time ago [46]. Oak samples were cored from trees in the Tsaghkunyats mountain range that borders the Ararat Plain to the north. The sampling site is located on the north-eastern slope of the Marmarik River valley in the vicinity of the Arzakan-Meghradzor Sanctuary protected area. The strong human impact, especially due to husbandry and overexploitation for industrial and domestic uses, has affected the age of the trees, which are relatively young and rarely exceed 120 years.

\subsection{Field Sampling and Laboratory Methods}

The samples were collected from three research sites (Table 1). Juniperus policarpos samples were taken from two sites at elevations of 1450-1550 m a.s.l. (Khosrov 1) and 1460-1650 m a.s.l. (Khosrov 2) in the Geggham Mountains (Figure 1). In the study areas, J. policarpos formed a tree and shrub habit with a maximum height of 10-15 m. A typical crown is pyramidal in young trees and broad and irregular in mature individuals (Figures 1C and 3). Dense and spreading first-order branches are a characteristic feature of the sampled trees. Quercus macranthera samples were collected at an elevation of 1820-1880 m a.s.l. in the vicinity of the Tezharuyk Monastery. The oak forest forms a homogeneous and compact community here, which is rare in central Armenia. It is part of a larger forest complex called the Hrazdan forest.

Table 1. Main site characteristics located in the Gegham Mountians and Tsaghkunyats Mountains.

\begin{tabular}{|c|c|c|c|c|c|c|}
\hline Site & $\begin{array}{c}\text { Latitude/ } \\
\text { Longitude }\end{array}$ & $\begin{array}{c}\text { Elevation m } \\
\text { a.s.l. }\end{array}$ & Exposition & $\begin{array}{c}\text { Slope } \\
\text { (Medium) }\end{array}$ & Geology & $\begin{array}{c}\text { Type of } \\
\text { Vegetation }\end{array}$ \\
\hline $\begin{array}{c}\text { Khosrov } 1 \\
\text { (Gegham Mts) }\end{array}$ & $\begin{array}{c}39^{\circ} 56^{\prime} 57^{\prime \prime} \mathrm{N} \\
44^{\circ} 55^{\prime} 31^{\prime \prime} \mathrm{E}\end{array}$ & $\begin{array}{c}1450 \\
-1550\end{array}$ & SW & $34^{\circ}$ & $\begin{array}{c}\text { Andesite and } \\
\text { andesitic-dacitic lava } \\
\text { flow (Quaternary) }\end{array}$ & $\begin{array}{l}\text { open juniper } \\
\text { forest }\end{array}$ \\
\hline $\begin{array}{c}\text { Khosrov } 2 \\
\text { (Gegham Mts) }\end{array}$ & $\begin{array}{l}40^{\circ} 07^{\prime} 16^{\prime \prime} \mathrm{N} \\
44^{\circ} 46^{\prime} 03^{\prime \prime} \mathrm{E}\end{array}$ & $\begin{array}{c}1460 \\
-1650\end{array}$ & SW & $18^{\circ}$ & $\begin{array}{c}\text { Andesite and } \\
\text { andesitic-dacitic lava } \\
\text { flow (Quaternary) }\end{array}$ & $\begin{array}{l}\text { open juniper } \\
\text { forest }\end{array}$ \\
\hline $\begin{array}{c}\text { Tezharuyk } \\
\text { (Tsaghkunyats } \\
\text { Mts) }\end{array}$ & $\begin{array}{l}40^{\circ} 35^{\prime} 52^{\prime \prime} \mathrm{N} \\
44^{\circ} 38^{\prime} 40^{\prime \prime} \mathrm{E}\end{array}$ & $\begin{array}{c}1820 \\
-1880\end{array}$ & SE & $25^{\circ}$ & $\begin{array}{c}\text { Volcanic and } \\
\text { volcanoclastic rocks } \\
\text { (Miocene-Pliocene) }\end{array}$ & dense oak forest \\
\hline
\end{tabular}



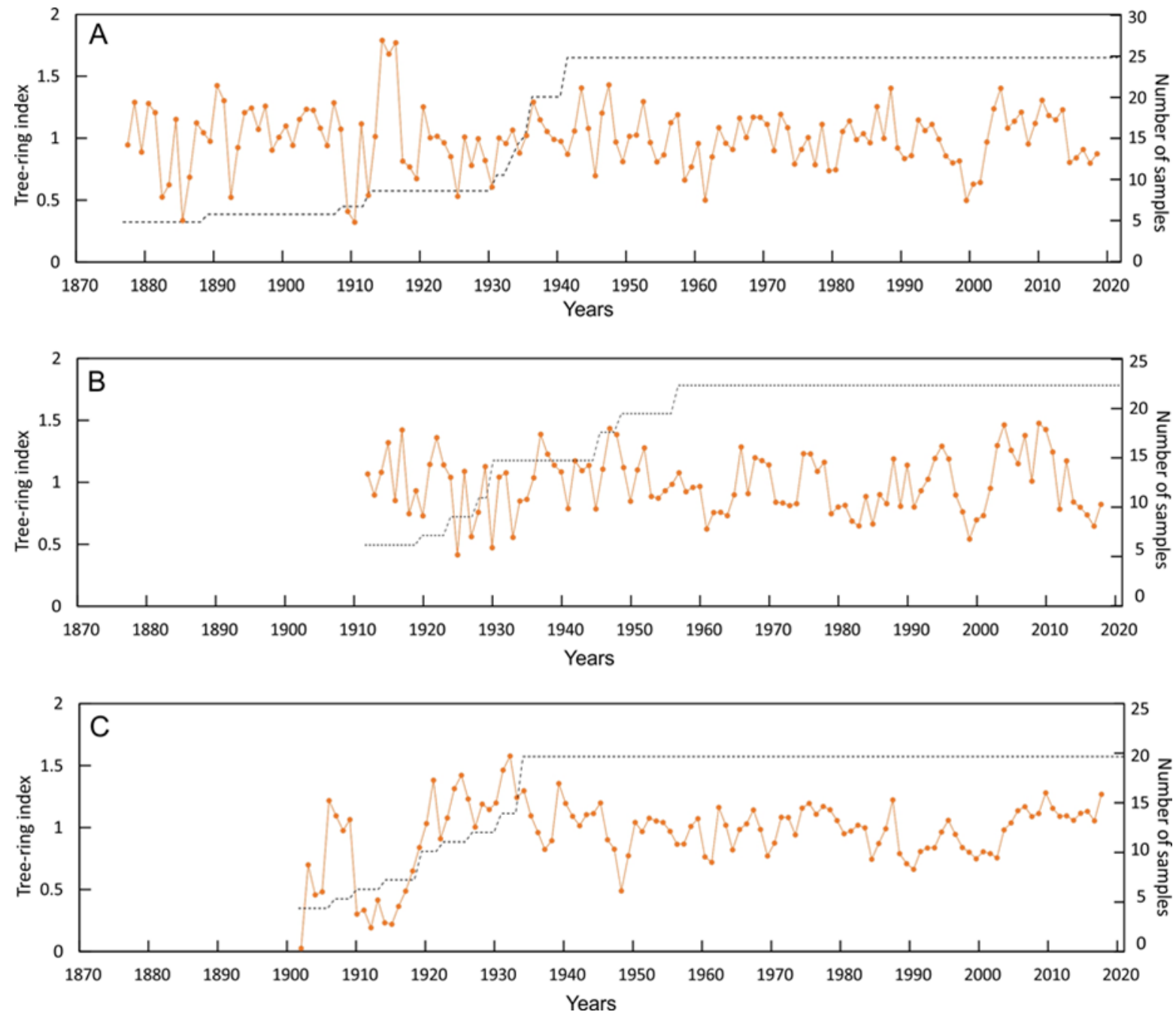

Figure 3. Tree-ring chronologies from Khosrov 1 (A), Khosrov 2 (B), and Tezharuyk (C).

A total of 90 trees (30 trees at each site) were sampled during the fieldwork in 2018. In general, one core was extracted from each tree using a Pressler borer due to the lack of access to the tree trunks. In the cases of distorted and irregular tree trunks, two cores were taken per tree to support cross-dating. Each tree was sampled at a height of $0.8-1.3 \mathrm{~m}$. The sampling strategy was dependent on the shape and density of the branches in the lower part of the tree trunk. In the laboratory, each core was air dried, mounted in a holder, and the surface of the cross-section was cut with a razor blade. Next, all cores were scanned at a resolution of $1200 \mathrm{dpi}$ and the annual ring widths were measured with an accuracy of $0.01 \mathrm{~mm}$ using WinDENDRO software. The quality of the dating and measurement was checked by the COFECHA program [47]. To remove nonclimatic trends resulting from age, size, and stand dynamics, the cross-dated raw ring widths were detrended using a negative exponential curve. The detrended individual time series of ring widths were averaged into a standard tree-ring width chronology and indexed using the ARSTAN program [48]. The same procedure was repeated for each sampling site. A reliable period of chronology was defined as a period with more than five samples and EPS (The Expressed Population Signal) above 0.85 .

\subsection{Climate Data and Dendroclimatological Analysis}

For comparison with climate factors, meteorological data (mean, minimum and maximum monthly average temperature, monthly total precipitation) from the Yerevan and Arabkir meteorological stations were used. Due to gaps in data and different time ranges of 
the meteorological series from Yerevan, the average mean of Merdzavan (1891-2018 with missing data in the early part of the series), Zvartnoc (1970-2007), and Agro (1961-2012) was calculated. Monthly values for the common period 1920-2018 were used in the analysis. We also used the gridded $0.5^{\circ} \times 0.5^{\circ} \mathrm{CRU}$ (Climatic Research Unit) data: mean temperature, maximum temperature, precipitation, cloud cover, self-calibrating Palmer Drought Severity Index (scPDSI), and CSIC (Consejo Superior de Investigaciones Científicas) monthly Standardized Precipitation-Evapotranspiration Index (SPEI) from the nearest grid $\left(40.0^{\circ} \mathrm{N}\right.$, $\left.44.5^{\circ} \mathrm{E}\right)$ and Black Sea-Caspian Sea region $\left(35-45^{\circ} \mathrm{N}, 38-53^{\circ} \mathrm{E}\right)$.

Climate-growth responses were analyzed for the period when both climate data (mean, min, max temperature, precipitation, cloud cover, scPDSI and SPEI) and tree-ring data were available-1920-2016. The calculations were carried out for the period of the previous and current growing seasons (previous year June to current year September). The importance of the dormant season (prior to the current growing season) is highlighted in many previous dendroclimatological studies $[49,50]$. The relationships between tree-ring chronology and climate were calculated using a correlation analysis and response function. All the calculations and significance tests were performed with the DENDROCLIM 2002 program, which enabled calculation of the bootstrap correlation coefficient using 1000 replicates for each data point in a random resampling [51]. Stability of climate-growth correlations were assessed by moving correlations which were calculated using 20-year moving intervals. The spatial pattern of climate-growth correlations were analyzed using gridded $0.5^{\circ} \times 0.5^{\circ}$ climate data over the period 1960-2000 for the Black Sea-Caspian Sea region and standard chronologies from our research sites. The influence of extreme climatic conditions on juniper and oak growth were described based on available meteorological records during the negative and positive years or characteristic periods. Negative and positive years were defined as calendar years when at least $75 \%$ of investigated trees were narrower or wider than the mean of the previous five years [52].

\section{Results and Discussion}

\subsection{Characteristics of Juniperus Polycarpos and Quercus Macranthera Tree-Ring Width Chronologies}

The tree-ring chronologies of juniper for both sites were similar by visual comparison and also by the statistical metrics (Table 2, Figure 3). From the 90 trees cored, only 69 sequences were successfully dated, even though additional samples from the same trees were also taken and used to support the cross-dating procedure. Due to the distorted and irregular tree trunks, missing rings and compression of wood occurred. In total, 21 individuals were excluded from further dendroclimatic analysis due to an irregular growth course resulting in a low interseries correlation. Juniperus polycarpos chronologies were developed, and their reliable lengths (>5 samples and EPS > 0.85) were at 104 (1914-2018) and 94 years (1924-2018), respectively. The oak chronology was based on 21 samples with a relatively good mean interseries correlation $(r>0.45)$. Reliable records with EPS $>0.85$ and $>5$ samples cover 99 years (1919 to 2018 CE) (Table 2). Collected older individuals were characterized by growth disturbances and thus were not integrated into the chronologies. A strong biological lag effect was indicated by the high first-order auto-correlation value of $0.565-0.768$ in the raw chronologies. Interestingly, no very high correlation was found between juniper chronologies $(r=0.66$ for the whole common period of 1920-2018, $r=0.51$ for 1920-1968, and $r=0.59$ for 1969-2018, $p<0.01$ ). Slightly lower were the correlations between the oak and the two juniper sites $(r=0.51$ and $r=0.53$ for whole common period of 1920-2018, $p<0.01 ; r=0.26$ and $r=0.21$ for 1920-1968, statistically insignificant; $r=0.45$ and $r=0.39$ for 1969-2018, $p<0.01$; for the Khosrov 1 and 2 sites, respectively). These results may indirectly indicate the increasing role of temperature in recent years, which is similarly unfavorable for both species. The ring width time-series indicate common periods with low $(1949,1961,1998-2003,2012-2018)$ and high $(1952,1988)$ growth variations or high variability (1941-1952). 
Table 2. Statistical characteristics of juniper chronologies from Gegham Mountains and oak chronology from Tsaghkunyats Mountains.

\begin{tabular}{cccccccc}
\hline Site & $\begin{array}{c}\text { Number of } \\
\text { Series Sam- } \\
\text { pled/Date }\end{array}$ & $\begin{array}{c}\text { Chronology } \\
\text { Time Span }\end{array}$ & $\begin{array}{c}\text { Reliable } \\
\text { Period } \\
\text { (>5 Samples) }\end{array}$ & $\begin{array}{c}\text { Reliable } \\
\text { Period } \\
\text { (EPS > 0.85) }\end{array}$ & $\begin{array}{c}\text { Mean Value } \\
\text { (mm) }\end{array}$ & $\begin{array}{c}\text { Series Inter- } \\
\text { correlation }\end{array}$ & $\begin{array}{c}\text { Mean } \\
\text { Sensitivity }\end{array}$ \\
\hline Khosrov 1 & $30 / 25$ & $1877-2018$ & $1890-2018$ & $1914-2018$ & 2.280 & 0.457 & 0.310 \\
\hline Khosrov 2 & $30 / 23$ & $1912-2018$ & $1912-2018$ & $1924-2018$ & 1.510 & 0.513 & 0.316 \\
\hline Tezharuyk & $30 / 21$ & $1902-2018$ & $1908-2018$ & $1919-2018$ & 1.890 & 0.446 \\
\hline
\end{tabular}

Even though developed tree-ring records for the Armenian part of the Lesser Caucasus are relatively short, covering the last 140 years, the obtained results are important for developing dendrochronology in the Black Sea-Caspian Sea region. Our new data are the first tree-ring width (TRW) chronologies for the central Lesser Caucasus. Little is also known for the eastern part of this region, where only a short record of Afghan pine was developed (1932-2010) for a single site in the Azerbaijan Republic [53]. Encouraging results from dendroclimatologial studies from the Greater Caucasus (Pinus sylvestris data from Baksan valley, Russia (1578-2006)) studied by [25], Pinus sylvestris data from Irik Valley, Russia (1800-2009) investigated by [23], from the Lesser Caucasus (Quercus petrea chronology (1651-2013)) from Turkey [35,36], and Pinus sylvestris chronology (1767-2006) from Georgia [34], indicate that it will be possible to obtain longer records. Additionally, results of studies from northern Iran showed the possibility of developing long, climate-sensitive tree-ring records based on the Juniperus polycarpos (1134-2016) TRW record developed by [54] and 1515-2015 $\delta^{18} \mathrm{O}$ data by [55] and Cupressus sempervirens (1615-2010 [56]) from the Alborz Mountain Range. Due to the current limitation and inaccessibility of the other sites in Armenia resulting from fire hazard, it was only possible to collect samples from the border zones of the nature reserves; however, in the future, it is possible to obtain tree samples from more distant parts of the reserves, extending to $400-500$ years.

\subsection{Climate and Tree-Growth Relationships}

Correlation function analysis results show that May precipitation and May-June temperatures have dominant control on the tree-ring formation of juniper in the Ararat Valley area (Figure 4). The results of the dendroclimatological analysis show that tree growth has a similar response to climatic factors at the two juniper sites, but almost all of the higher responses were found at the Khosrov 1 site. The positive influence of precipitation $(r=0.50)$ and the negative influence of temperature $(r=-0.51)$ suggest drought stress at the investigated sites. These results are confirmed by the result of the correlation analysis between tree-ring data and drought indexes. In fact, the highest correlation was obtained for scPDSI from May to September and SPEI from April to June (Figure 4). Climatic conditions during the dormant period are of less importance. Oak growth ring chronology has a positive response to May precipitation, as well, but the correlation value is lower $(r=0.32)$ than those for juniper. The positive response to summer temperature is shifted to June-July $(r=0.39-0.40)$. Similar to juniper, oak TRW showed distinct associations with drought indexes at monthly and seasonal scales (Figure 4).

In the western part of Lesser Caucasus (Turkey and Georgia sites), Pinus sylvestris and Quercus petrea trees show a distinct May-June precipitation signal [28,57], which is similar to our results from the central part of Lesser Caucasus where May precipitation signal dominates both in Juniperus and Quercus sites. In the Armenian sites, mean temperatures are more highly correlated with the juniper chronology than maximum or minimum temperatures, resulting from rising minimum temperature and reducing the temperature amplitude. This relation is less clear for Quercus. Differently, in the western Lesser Caucasus region, a strong negative correlation with temperature was observed only for Quercus and was not the case for other species [57]. Junipers from the lower location in northern Iran are sensitive to spring precipitation and PDSI during the spring and summer months [58]. 
At the upper treeline site in the Alborz Mountains, mean temperature in the March-July period had the highest correlation with the juniper chronology [54]. Growth rates of cypress from Alborz highlands are limited by annual moisture conditions, expressed by the aridity index of De Martonne [56].

Khosrov 1
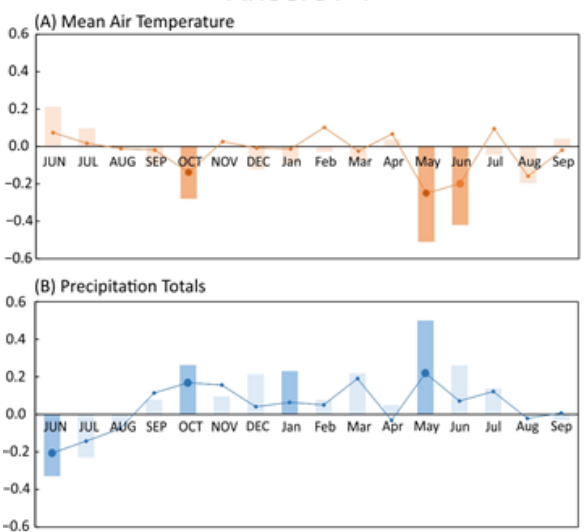

0.6 (C) Standardized Precipitation-Evapotranspiration Index (SPEI)

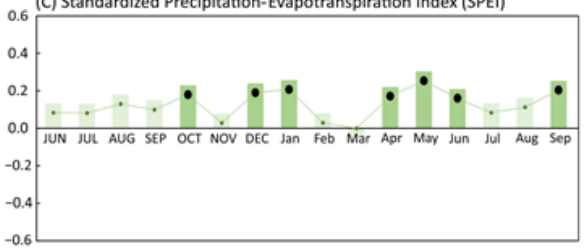

(D) Self-calibrating Palmer Drought Severity Index (scPDSI)

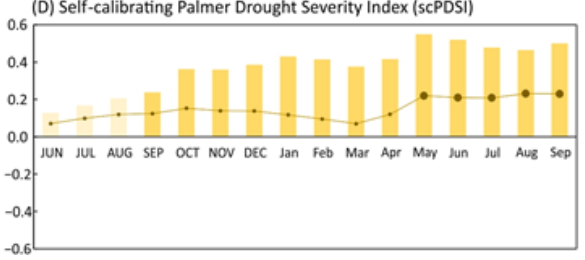

Khosrov 2
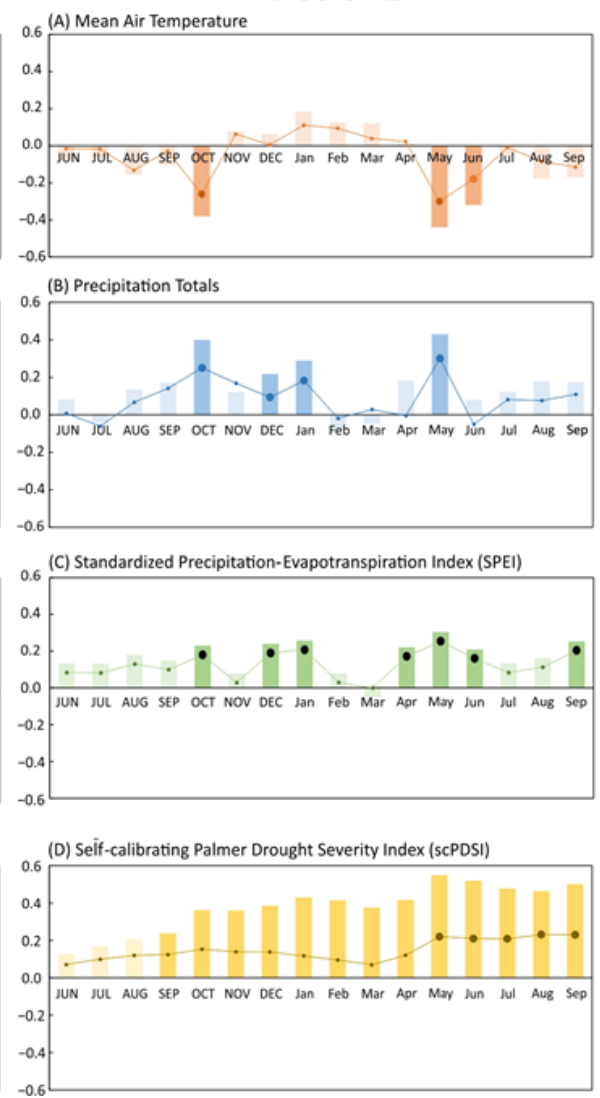

Tezharuyk
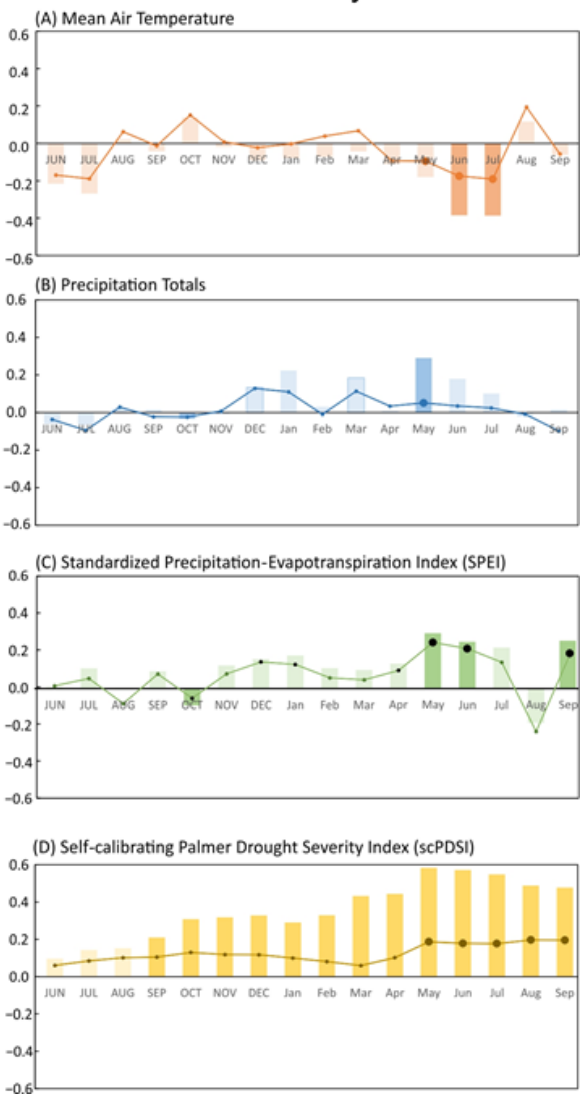

Figure 4. Correlation (bars) and response function (dots) coefficients between the juniper (Khosrov 1 and 2) and oak (Tezharuyk) chronologies and climate variables and drought indexes (A-D) from June of the previous year to September of the current year over the period 1920-2018. Dark bars and dots indicate significance at the 95\% level of confidence.

\subsection{Stability of Climate-Growth Correlations}

The juniper and oak chronologies were used to analyze time-varying tree-ring growth responses to climate (annual air temperature and total precipitation data for the period 1960-2016). Time-dependent moving correlation analysis indicated that juniper data showed positive correlation with annual precipitation and temperature up to about 1990, then correlation with precipitation increased significantly (to 0.75 ), while correlation with temperature dropped sharply and became negative (statistically insignificant). The oak tree-ring width data showed increased positive correlations with precipitation after 1998 and with temperature after $2000(p<0.05)$ (Figure 5). Moving correlation analysis indicated a significant change over time in the sensitivity of investigated trees to climatic variability, although this was manifested in different ways.

A significant growth decrease is visible for the juniper tree-ring width chronologies of recent years (Figure 3). This indicates that juniper growth, previously favored by warm spring-summer temperatures, has become negatively affected by increasing summer aridity in recent decades. Climate change, manifested as an accelerated warming trend and decreases in precipitation, observed in Armenia led to increased drought stress of juniper and oak trees, which can also be visible as distinct growth reduction. The summer warming (during 1981-2009) is also well preserved in the dendroclimatological record 
of Pinus sylvestris from Irik Valley, near Elbrus glacier in Greater Caucasus, Russia, as reported by [23]. However, these data are primarily sensitive to summer temperature, and no significant correlation with precipitation was found.
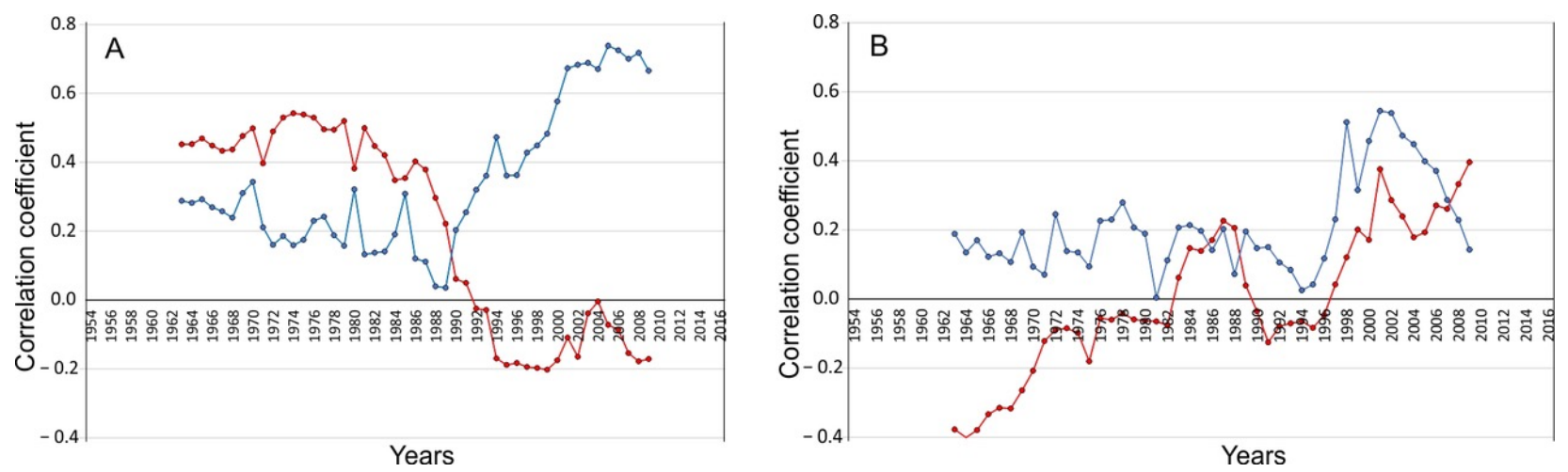

Figure 5. Moving correlation analysis (20-years window) showing influence of annual precipitation (blue line) and temperature (red line) on juniper (Khosrov 1 site) (A) and oak (Tezharuyk site) (B) tree-ring width chronologies.

\subsection{Spatial Pattern of Climate-Growth Correlations}

Regarding the spatial responses to climatic variables, the chronologies of both species showed the strongest negative correlation with temperature; however, the response to the maximum temperature covers a spatially larger area, including eastern Turkey, northern Iran and Iraq, and western Azerbaijan (Figures 6 and 7). In the case of juniper TRW chronology, correlation with both precipitation and cloud cover is positive and covers a similar area. The spatial field correlation map showing the statistical relationship between the drought indexes and juniper TRW chronology shows that the PDSI signal is stronger but covers a smaller area-only the central Lesser Caucasus including Armenia and northeastern Turkey. The SPEI signal is weaker but covers a larger territory. For the spatial responses of oak TRW chronology to drought indexes, a small spatial range is characteristic, both for SPEI and PDSI.
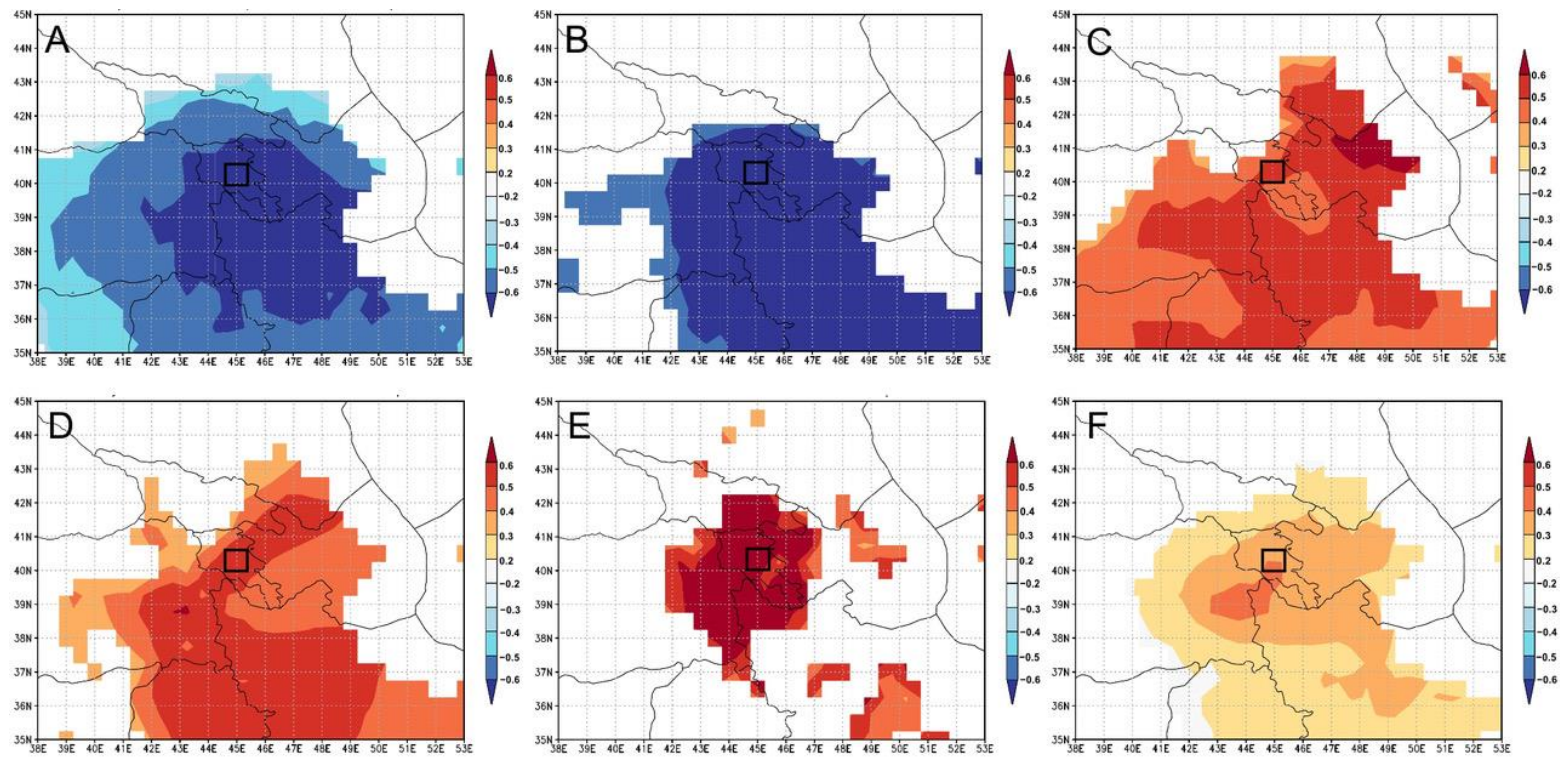

Figure 6. Spatial correlations between the juniper chronology and (A) May gridded mean temperature (CRU TS4.04), (B) May gridded maximum temperature (CRU TS4.04), (C) May gridded precipitation (CRU TS4.04), (D) May cloud cover (CRU TS4.04), (E) July scPDSI (CRU, 3.26e), and (F) May SPEI (CSIC) for the period 1960-2000. Only significant $(p<0.05)$ correlation is shown. 

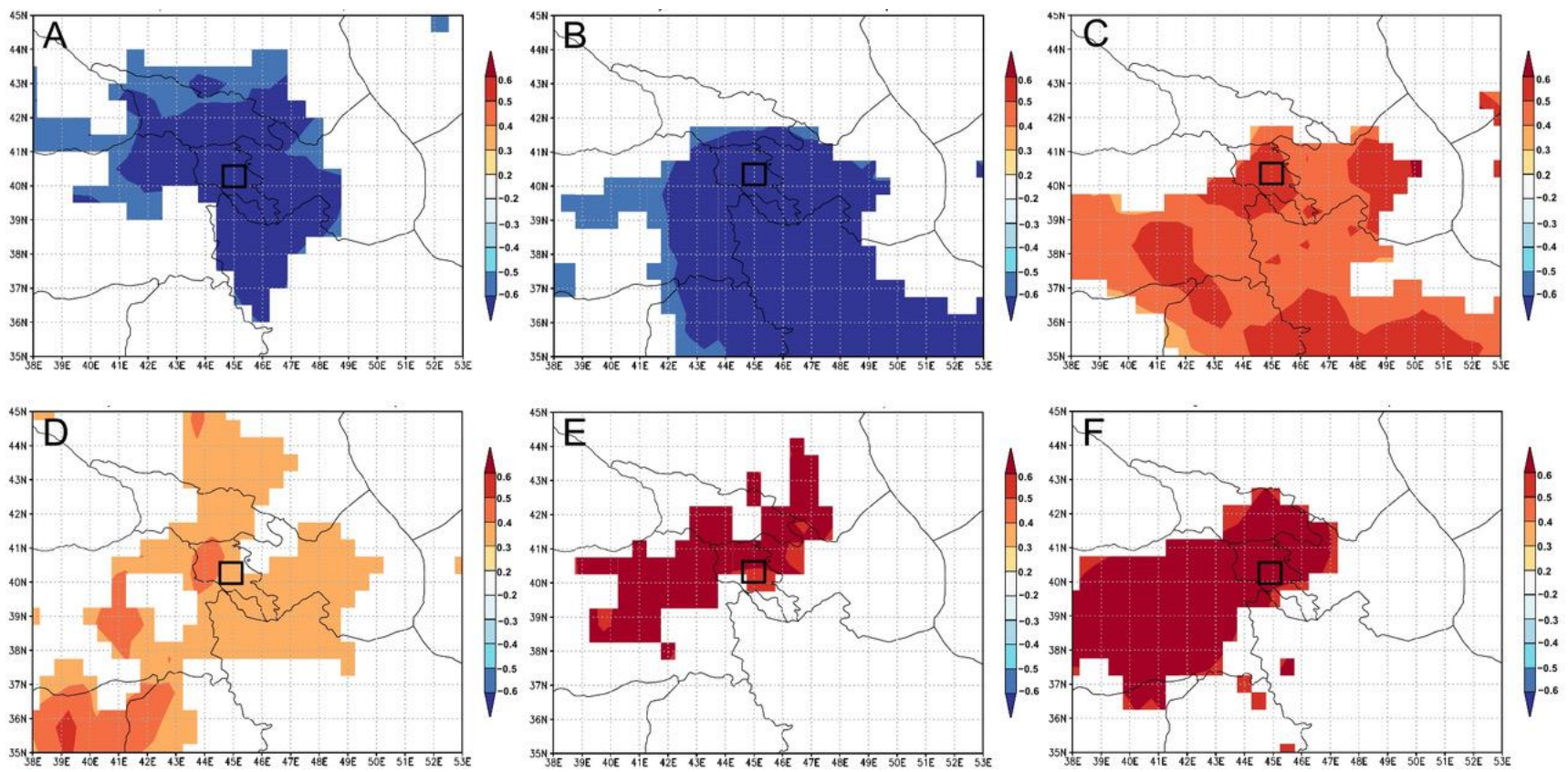

Figure 7. Spatial correlations between the oak chronology and (A) September gridded surface temperature (CRU TS4.04), (B) May gridded maximum temperature (CRU TS4.04), (C) May gridded precipitation (CRU TS4.04), (D) May cloud cover (CRU TS4.04), (E) July scPDSI (CRU, 3.26e), and (F) August SPEI (CSIC) for the period 1960-2000 at $0.5^{\circ}$ intervals. Only significant $(p<0.05)$ correlation is shown.

In future research, it might be interesting to investigate the connection between treering records and atmospheric teleconnections as they can affect the patterns and occurrence of megadroughts and pancontinental droughts over the CE [59].

\subsection{Influence of Extreme Climatic Conditions on Juniper and Oak Growth}

To investigate similarities between dendrochronological records in Armenia and other discussed parts of the Black Sea-Caspian Sea region, we compared extreme years during the 20th century with different chronologies (Table 3). In general, severe droughts emerging in the 20th century affected the whole region around our study site. Especially visible in tree-ring records are severe prolonged droughts-1998-2003 and 2012-2018reaching over the whole Lesser Caucasus region and the southern coast of the Caspian Sea [55]. During these years, summer months without or with a very low amount of precipitation dominate. Extremely dry years in our record-1941, 1949, and 1961—showed good agreement with those described for western Lesser Caucasus [28]. Only one common wet year (1988) was identified. Interestingly many extreme years present in the Lesser Caucasus chronologies from Georgia, Turkey, and Armenia were not present in Iran but occurred a year after in Alborz Mountain's chronology. The presented results indicate the occurrence of multiannual droughts recorded by tree rings, which could have potentially negative effects on agriculture; thus, there is a need for further dendroclimatological fieldwork in Armenia to extend the records back in time to assess the drought from a longer perspective. 
Table 3. The influence of extreme climatic conditions on juniper and oak growth in 20th century in central Lesser Caucasus in comparison to other dendroclimatological research in the Black Sea-Caspian Sea region.

\begin{tabular}{|c|c|c|c|c|}
\hline $\begin{array}{c}\text { Extreme } \\
\text { Year/Period }\end{array}$ & Characteristics & $\begin{array}{c}\text { Corresponding } \\
\text { Meteorological Conditions }\end{array}$ & $\begin{array}{l}\text { Western Lesser } \\
\text { Caucasus [28] }\end{array}$ & $\begin{array}{l}\text { Alborz Mountain } \\
\text { Northern Iran [55] }\end{array}$ \\
\hline 1941-1952 & High variability & $\begin{array}{l}\text { large variation in rainfall } \\
\text { conditions }\end{array}$ & $\begin{array}{c}\text { Dry years: } 1941,1943, \\
1949\end{array}$ & Dry years: 1942, 1947 \\
\hline 1949 & Negative year & $\begin{array}{l}\text { High mean maximum } \\
\text { temperatures in June and July } \\
\left(>35^{\circ} \mathrm{C}\right) \text { and very dry summer } \\
\text { (only } 1 \mathrm{~mm} \text { of precipitation } \\
\text { during June and July) }\end{array}$ & Dry year & - \\
\hline 1961 & Negative year & $\begin{array}{c}\text { very dry summer (only } 1.1 \mathrm{~mm} \\
\text { of precipitation during } \\
\text { July-September) }\end{array}$ & Dry year & Dry year: 1962 \\
\hline 1988 & Positive year & $\begin{array}{l}\text { High amount of precipitation } \\
\text { in May; moderate maximum } \\
\text { temp, and high minimum } \\
\text { temperature }\end{array}$ & Wet year & - \\
\hline 1998-2003 & $\begin{array}{l}\text { Period of low } \\
\text { growth }\end{array}$ & $\begin{array}{l}\text { Extremely low amount of } \\
\text { summer precipitation }\end{array}$ & - & 1998,2000 \\
\hline 1999 & Negative year & $\begin{array}{c}\text { High mean temperature in } \\
\text { August }\left(27^{\circ} \mathrm{C}\right) \text { and very dry } \\
\text { summer }(0 \mathrm{~mm} \text { of precipitation } \\
\text { in August })\end{array}$ & - & - \\
\hline 2004 & Positive year & Normal conditions & - & 2005 \\
\hline 2012-2018 & $\begin{array}{l}\text { Period of low } \\
\text { growth }\end{array}$ & $\begin{array}{l}\text { High maximum temperatures } \\
\text { during summer, low summer } \\
\text { precipitation }\end{array}$ & - & 2015 \\
\hline
\end{tabular}

\section{Conclusions}

We have developed three new tree-ring width chronologies of Juniperus and Quercus from the Lesser Caucasus in central Armenia. These new sites constitute drought-sensitive tree-ring width chronologies. Our research demonstrated that the juniper in the Lesser Caucasus is a very promising climatic proxy, especially for reconstructions of past precipitation. The warming observed in summer temperature since 1980 is well preserved in our data. Ongoing climate change increases the drought stress of juniper trees. The first 140-year record of droughts in Armenia is vital as it can present the ongoing climatic changes in a longer time context and support the prediction of the range of dry weather conditions that are of value for a country where agriculture is strongly dependent on irrigation. The obtained results of the first dendroclimatological investigation in Armenia are promising; however, at this point, the time span of the records is somehow limited, and more sampling work in different parts of the country is still needed. Due to the limited lengths of the Armenian chronologies obtained to date, we cannot discuss centennial variations in the dendroclimatological records. Forthcoming dendroclimatological studies can enable the expansion of pioneering tree-ring chronologies to improve the understanding of long-term precipitation variability in Armenia which will allow for the improvement of dendrochronological dating of archeological wood.

Author Contributions: Conceptualization, M.O.-O., H.G. and P.O.; methodology, writing and original draft preparation, M.O.-O.; field investigation, H.G., P.O., M.O.-O.; visualization, P.O.; validation, M.O.-O. and P.O.; resources, H.S. and T.V. All authors have read and agreed to the published version of the manuscript. 
Funding: This research was supported by project Number 2018/02/X/ST10/00573 funded by the Polish National Research Centre.

Institutional Review Board Statement: Not applicable.

Informed Consent Statement: Not applicable.

Data Availability Statement: The data presented in this study are available on request from the corresponding author. The data are not publicly available due to ongoing study.

Acknowledgments: The authors gratefully acknowledge Hrachya Hovakimyan, director of the "Khosrov Forest State Reserve", for permission to conduct tree-ring sampling and her help during field work. The authors also thank the Yerevan State University Hydrometeorological laboratory staff for providing meteorological data. The authors sincerely thank the four reviewers whose constructive comments and suggestions improved the quality of the paper.

Conflicts of Interest: The authors declare no conflict of interest. The funders had no role in the design of the study; in the collection, analyses, or interpretation of data; in the writing of the manuscript, or in the decision to publish the results.

\section{References}

1. Gevorgyan, A. Main types of synoptic processes and circulation types generating heavy precipitation events in Armenia. Meteorol. Atmos. Phys. 2013, 122, 91-102. [CrossRef]

2. Galstyan, H.; Sfîcă, L.; Ichim, P. Long Term Variability of Annual Temperature in Armenia in the Context of Changing Climate. Int. J. Environ. Chem. Ecol. Geol. Geophys. Eng. 2016, 10, $19-25$.

3. Alexandryan, G. Precipitation in the Armenian SSR; Yerevan, Armenia, 1971; pp. 1-178. (In Russian)

4. Melkonyan, A.; Asadoorian, M.O. Climate impact on agroeconomy in semiarid region of Armenia. Environ. Dev. Sustain. 2014, 16, 393-414. [CrossRef]

5. Gevorgyan, A. Verification of daily precipitation amount forecasts in Armenia by ERA-Interim model. Int. J. Clim. 2012, 33, 2706-2712. [CrossRef]

6. Saiadian, Y. Lake Sevan-Natural climatogram of the Holocene. In Voprosy Geologii Golotsena; Yerevan, Armenia, $1985 ;$ pp. 61-67. (In Russian)

7. Gorbatov, E.S.; Vardanyan, A.A.; Korzhenkov, A.M.; Razumniy, S.D. Lake Sevan (Armenia) Deposits as Indicator of Paleoclimate and Neotectonic Processes. Izv. Atmos. Ocean. Phys. 2019, 55, 860-869. [CrossRef]

8. Ollivier, V.; Joannin, S.; Roiron, P.; Nahapetyan, S.; Chataigner, C. Travertinization and Holocene morphogenesis in Armenia: A reading grid of rapid climatic changes impact on the landscape and societies between 9500-4000 cal. BP in the Circumcaspian regions? Eur. Archaeol. 2011, 36, 26-31.

9. Joannin, S.; Ali, A.A.; Ollivier, V.; Roiron, P.; Peyron, O.; Chevaux, S.; Nahapetyan, S.; Tozalakyan, P.; Karakhanyan, A.; Chataigner, C. Vegetation, fire and climate history of the Lesser Caucasus: A new Holocene record from Zarishat fen (Armenia). J. Quat. Sci. 2014, 29, 70-82. [CrossRef]

10. Bradley, R.S. Paleoclimatology: Reconstructing Climates of the Quaternary, 3rd ed.; Elsevier/Academic: Amsterdam, The Netherlands, 2015; pp. 1-696.

11. Fritts, H.C. Tree Rings and Climate; Academic Press: New York, NY, USA, 1976; pp. 1-582.

12. Dobbertin, M. Tree growth as indicator of tree vitality and of tree reaction to environmental stress: A review. Eur. J. For. Res. 2005, 124, 319-333. [CrossRef]

13. Schuster, R.; Oberhuber, W. Drought sensitivity of three co-occurring conifers within a dry inner Alpine environment. Trees 2013, 27, 61-69. [CrossRef]

14. Pederson, N.; Jacoby, G.C.; D'Arrigo, R.D.; Cook, E.R.; Buckley, B.M.; Dugarjav, C.; Mijiddorj, R. Hydrometeorological Reconstructions for Northeastern Mongolia Derived from Tree Rings: 1651-1995. J. Clim. 2001, 14, 872-881. [CrossRef]

15. Davi, N.K.; Jacoby, G.C.; D’Arrigo, R.D.; Baatarbileg, N.; Jinbao, L.; Curtis, A.E. A tree-ring based drought index reconstruction for far western Mongolia: 1565-2004. Int. J. Clim. 2009, 29, 1508-1514. [CrossRef]

16. Li, J.; Gou, X.; Cook, E.R.; Chen, F. Tree-ring based drought reconstruction for the central Tien Shan area in northwest China. Geophys. Res. Lett. 2006, 33, L07715. [CrossRef]

17. Chen, F.; Yuan, Y.J.; Wei, W.S.; Yu, S.L.; Zhang, T.W.; Shang, H.M.; Zhang, R.; Qin, L.; Fan, Z. Tree-ring recorded hydroclimatic change in Tienshan mountains during the past 500 years. Quat. Int. 2015, 358, 35-41. [CrossRef]

18. Opała, M.; Niedźwiedź, T.; Rahmonov, O.; Owczarek, P.; Małarzewski, Ł. Towards improving the Central Asian dendrochronological network-New data from Tajikistan, Pamir-Alay. Dendrochronologia 2017, 41, 10-23. [CrossRef]

19. Opała-Owczarek, M.; Niedźwiedź, T. Last 1100 yr of precipitation variability in western central Asia as revealed by tree-ring data from the Pamir-Alay. Quat. Res. 2019, 91, 81-95. [CrossRef] 
20. Opała-Owczarek, M.; Owczarek, P. Dry and Humid Periods Reconstructed from Tree Rings in the Former Territory of Sogdiana (Central Asia) and Their Socio-economic Consequences over the Last Millennium. In Socio-Environmental Dynamics along the Historical Silk Road; Yang, L., Bork, H.R., Fang, X., Mischke, S., Eds.; Springer: Cham, Switzerland, 2019; pp. 195-214. [CrossRef]

21. Azizi, G.; Arsalani, M.; Bräuning, A.; Moghimi, E. Precipitation variations in the central Zagros Mountains (Iran) since A.D. 1840 based on oak tree rings. Palaeogeogr. Palaeoclim. Palaeoecol. 2013, 386, 96-103. [CrossRef]

22. Arsalani, M.; Pourtahamsi, K.; Azizi, G.; Bräuning, A.; Mohammadi, H. Tree-ring based December-February precipitation reconstruction in the southern Zagros Mountains, Iran. Dendrochronologia 2018, 49, 45-56. [CrossRef]

23. Holobâcă, I.-H.; Pop, O.; Petrea, D. Dendroclimatic reconstruction of late summer temperatures from upper treeline sites in Greater Caucasus, Russia. Quat. Int. 2016, 415, 67-73. [CrossRef]

24. Dolgova, E.A.; Solomina, O.N. First quantitative reconstruction of air temperature for the warm period in the Caucasus based on dendrochronological data. Dokl. Earth Sci. 2010, 431, 252-256. [CrossRef]

25. Brugnoli, E.; Solomina, O.; Spaccino, L.; Dolgova, E. Climate signal in the ring width, density and carbon stable isotopes in pine (Pinus Sylvestris L.) in Central Caucasus. Geogr. Environ. Sustain. 2010, 3, 4-16. [CrossRef]

26. Dolgova, E. June-September temperature reconstruction in the Northern Caucasus based on blue intensity data. Dendrochronologia 2016, 39, 17-23. [CrossRef]

27. Köse, N.; Güner, H.T.; Harley, G.L.; Guiot, J. Spring temperature variability over Turkey since 1800CE reconstructed from a broad network of tree-ring data. Clim. Past 2017, 13, 1-15. [CrossRef]

28. Martin-Benito, D.; Ummenhofer, C.C.; Köse, N.; Güner, H.T.; Pederson, N. Tree-ring reconstructed May-June precipitation in the Caucasus since 1752 CE. Clim. Dyn. 2016, 47, 3011-3027. [CrossRef]

29. Jude, F.; Marguerie, D.; Badalyan, R.; Smith, A.T.; Delwaide, A. Wood resource management based on charcoals from the Bronze Age site of Gegharot (central Armenia). Quat. Int. 2016, 395 (Suppl. C), 31-44. [CrossRef]

30. Adamia, S.A.; Chkhotua, T.; Kekelia, M.; Lordkipanidze, M.; Shavishvili, I.; Zakariadze, G. Tectonics of the Caucasus and adjoining regions: Implications for the evolution of the Tethys ocean. J. Struct. Geol. 1981, 3, 437-447. [CrossRef]

31. Adamia, S.A.; Zakariadze, G.; Chkhotua, T.; Sadradze, N.; Tsereteli, N.; Chabukiani, A.; Gventsadze, A. Geology of the Caucasus: A Review. Turk. J. Earth Sci. 2011, 20, 489-544. [CrossRef]

32. Arutyunyan, E.V.; Lebedev, V.A.; Chernyshev, I.V.; Sagatelyan, A.K. The geochronology of the Neogene/Quaternary volcanism in the Geghama highland, Lesser Caucasus, Armenia. In Doklady Earth Sciences; Springer: Berlin/Heidelberg, Germany, 2007; Volume 416, pp. 91-95. [CrossRef]

33. Lebedev, V.A.; Chernyshev, I.V.; Shatagin, K.N.; Bubnov, N.; Yakushev, A.I. The quaternary volcanic rocks of the Geghama highland, Lesser Caucasus, Armenia: Geochronology, isotopic Sr-Nd characteristics, and origin. J. Volcanol. Seism. 2013, 7, 204-229. [CrossRef]

34. ITRDBa, Chronologies Archived at the International Tree-Ring Data Bank Developed by (a) U. Buentgen, A. Nievergelt, A. Verstege. Available online: https://www.ncdc.noaa.gov/paleo-search/study/13877 (accessed on 10 May 2020).

35. ITRDBb, Chronologies Archived at the International Tree-Ring Data Bank developed by (a) N. Riches and P.I. Kuniholm. Available online: https: / / www.ncdc.noaa.gov / paleo-search/study / 4235 (accessed on 10 May 2020).

36. ITRDBc, Chronologies Archived at the International Tree-Ring Data Bank Developed by (a) P.I. Kuniholm. Available online: https:/ / www.ncdc.noaa.gov/paleo-search/study/3808 (accessed on 10 May 2020).

37. Lydolph, P.E. Climates of the Soviet Union; Elsevier Scientific Publishing Company: Amsterdam, The Netherlands; New York, NY, USA, 1977; pp. 1-443.

38. Gidrometeoizdat. Scientific and Applied Reference Book on the Climate of the USSR. Long-Term Data; Part 1-6, Issue 16; Gidrometeoizdat: Saint Petersburg, Russia, 1989. (In Russian)

39. Galstyan, H.; Vardanyan, T. The Dynamics of Average Annual Air Temperature Changes in the Republic of Armenia. Proc. Ysu Ser. Geol. Geogr. 2017, 51, 68-71.

40. Gevorgyan, A. Surface and tropospheric temperature trends in Armenia. Int. J. Climatol. 2014, 34, 3559-3573. [CrossRef]

41. Bamston, A.G.; Livezey, R.E. Classification, Seasonality and Persistence of Low-Frequency Atmospheric Circulation Patterns. Mon. Weather Rev. 1987, 115, 1083-1126. [CrossRef]

42. Xoplaki, E.; González-Rouco, J.F.; Luterbacher, J.; Wanner, H. Wet season Mediterranean precipitation variability: Influence of large-scale dynamics and trends. Clim. Dyn. 2004, 23, 63-78. [CrossRef]

43. Galstyan, H.; Sfîcă, L.; Ichim, P. Long Term Variability of Annual Precipitation in Armenia in the Context of Changing Climate. An. Stiint. Univ. Alexandru Ioan Cuza Iasi-Ser. Geogr. 2015, 60, 5-16.

44. Khosrov Forest State Preserve. Available online: http://www.armeniapedia.org/index.php?title=Khosrov_Forest_State_Preserve (accessed on 22 November 2020).

45. Gabrielian, E.T.S. The conservation of rare threatened species and types of vegetation in Armenia. In Anales del Jardín Botánico de Madrid; Real Jardín Botánico: Madrid, Spain, 1981; Volume 37, pp. 773-778.

46. Sayadyan, H.; Moreno-Sanchez, R. Forest policies, management and conservation in Soviet (1920-1991) and post-Soviet (19912005) Armenia. Environ. Conserv. 2006, 33, 60-72. [CrossRef]

47. Holmes, R.L. Program COFECHA User's Manual; Laboratory of Tree-Ring Research, University of Arizona: Tucson, AZ, USA, 1983.

48. Cook, E.R. A Time Series Approach to Tree-Ring Standardization. Ph.D. Thesis, University of Arizona, Tucson, AZ, USA, 1985. 
49. D'Arrigo, R.; Mashig, E.; Frank, D.; Wilson, R.; Jacoby, G. Temperature variability over the past millennium inferred from Northwestern Alaska tree rings. Clim. Dyn. 2005, 24, 227-236. [CrossRef]

50. Opała, M.; Mendecki, M.J. An attempt to dendroclimatic reconstruction of winter temperature based on multispecies tree-ring widths and extreme years chronologies (example of Upper Silesia, Southern Poland). Theor. Appl. Climatol. 2014, 115, 73-89. [CrossRef]

51. Biondi, F.; Waikul, K. DENDROCLIM 2002: A C++ program for statistical calibration of climate signals in tree-ring chronologies Comput. Geosci. 2004, 30, 303-311. [CrossRef]

52. Schweingruber, F.H.; Eckstein, D.; Serre-Bachet, F.; Bracker, O.U. ldentification, presentation and interpretation ofevent years and pointer years in dendrochronology. Dendrochronologia 1990, 8, 9-38.

53. Balapour, S.; Mammadov, T.; Gerayeli, S. Investigation of Climate Impact on Afghan Pine (Pinus eldarica) Using Dendrochronological Methods. J. For. Wood Prod. 2015, 67, 657-666.

54. Bayramzadeh, V.; Zhu, H.; Lu, X.; Attarod, P.; Zhang, H.; Li, X.; Asad, F.; Liang, E. Temperature variability in northern Iran during the past 700 years. Sci. Bull. 2018, 63, 462-464. [CrossRef]

55. Foroozan, Z.; Grießinger, J.; Pourtahmasi, K.; Bräuning, A. 501 Years of Spring Precipitation History for the Semi-Arid Northern Iran Derived from Tree-Ring $\delta 18 \mathrm{O}$ Data. Atmosphere 2020, 11, 889. [CrossRef]

56. Gholami, V.; Ahmadi Jolandan, M.; Torkaman, J. Evaluation of climate change in northern Iran during the last four centuries by using dendroclimatology. Nat. Hazards 2017, 85, 1835-1850. [CrossRef]

57. Martin-Benito, D.; Pederson, N.; Köse, N.; Doğan, M.; Bugmann, H.; Mosulishvili, M.; Bigler, C. Pervasive effects of drought on tree growth across a wide climatic gradient in the temperate forests of the Caucasus. Glob. Ecol. Biogeogr. 2018, 27, 1314-1325. [CrossRef]

58. Pourtahmasi, K.; Bräuning, A.; Poursartip, L.; Burchardt, I. Growth-climate responses of oak and juniper trees in different exposures of the Alborz Mountains, northern Iran. In Proceedings of the DENDROSYMPOSIUM 2011, TRACE 10, Orléans, France, 11-14 May 2011; pp. 49-53.

59. PAGES Hydro2k Consortium. Comparing proxy and model estimates of hydroclimate variability and change over the Common Era. Clim. Past. 2017, 13, 1851-1900. [CrossRef] 